\title{
KEMANDIRIAN PONDOK PESANTREN MELALUI PENDIRIAN BISNIS LEMBAGA KEUANGAN DI KABUPATEN PAMEKASAN
}

\author{
Nailah Aka Kusuma, Jamiatul Uyun, \& Evi Malia \\ Universitas Islam Madura (Indonesia); \\ nailahakakusuma@gmail.com
}

\begin{abstract}
Abstrak:
Kemandirian pondok pesatren akan terwujud apabila pondok pesantren bisa memenuhi kebutuhan dan biaya penyelenggaraan pendidikkannya sendiri tanpa bergantung pada pihak eksternal pondok pesantren. Penelitian ini bertujuan untuk mengetahui bagaimana kemandirian dari pondok pesantren yang memiliki usaha bisnis berupa lembaga keuangan dan kemandirian dari pondok pesantren yang tidak memiliki usaha bisnis. Metode penelitian yang digunakan dalam penelitian ini yaitu kualitatif deskriptif dengan melakukan wawancara dan observasi langsung kepada informan yang berkaitan dalam variabel penelitian ini. Objek penelitian ini adalah pada pondok pesantren yang ada di Pamekasan. Hasil dari penelitian ini yaitu adanya bisnis pondok pesantren dapat menciptakan pondok pesantren yang mandiri dan tidak tergantung terhadap pihak ketiga baik itu pemerintah maupun alumni santri serta iuran dari santri, namun dengan adanya lembaga keuangan mikro syariah mampu memberikan kontribusi kepada pondok pesantren setiap tahun dari sisa hasil usaha (SHU) yang didapatkan dari lembaga keuangan mikro syariah, keuntungan juga diperoleh dari usaha bisnis pesantren yang lainnya.
\end{abstract}

Keywords: Pondok Pesantren, Lembaga Keuanngan Syariah, Kemandirian.

\begin{abstract}
:
The independence of the pondok rapidly will be realized if the boarding schools can meet the needs and costs of conducting their own education without depending on external parties of the pesantren. This study aims to determine how independent Islamic boarding schools have business businesses in the form of financial institutions and the independence of Islamic boarding schools that do not have business. The research method used in this research is descriptive qualitative by conducting interviews and direct observation to informants who are related to this research variable. The object of this research is the Islamic boarding school in Pamekasan. The result of this research is that the existence of an Islamic boarding school business can create an independent Islamic boarding school and does not depend on third parties, both the government and santri alumni as well as contributions from students, but with the existence of Islamic microfinance institutions it only contributes to the boarding school every year from the remaining results. business (SHU) obtained from Islamic microfinance institutions, profits are also obtained from other Islamic boarding school businesses.
\end{abstract}

Keywords: Islamic boarding schools, Islamic financial institutions, independence. 


\section{Pendahuluan}

Lembaga Pondok pesantren saat ini mempunyai daya tarik tersendiri, disamping saat ini pondok pesantren tidak lagi merupakan lembaga pendidikan yang dahulunya terkesan tradisional dan ketinggalan zaman yang hanya menyediakan pendidikan informal saja, namun di era modern saat ini lembaga pondok pesantren sudah mengepakkan sayap dengan juga mendirikan lembaga formal yang tidak terbatas pada tingkat menengah atas namun ada juga yang sampai dengan tingkat perguruan tinggi. Selain itu banyak pondok pesantren juga merambah pada bidang bisnis, banyak pesantren yang mendirikan dan menjalankan bisnis yang bertujuan untuk menjunjung kemandirian pondok pesantren itu sendiri dalam menghadapi era globalisasi saat ini sehingga pondok pesantren tidak terkooptasi pada kepentingan - kepentingan eksternal seperti halnya pemerintah.

Perkembangan pondok pesantren untuk mendirikan lembaga bisnis tidak terlepas dari keinginan dari pondok pesantren saat ini untuk menjadi pesantren yang mandiri dan maju tanpa ada ketergantungan kepada pihak eksternal seperti pemerintah. Kemandirian pesantren saat ini patut diacungkan jempol mengingat sejak tahun 1970-an pondok pesantren sudah berbenah untuk melakukan upaya reposisi dalam menyikapi berbagai persoalan sosial masyarakat, yang diantaranya adalah persoalan ekonomi keumatan sehingga pesantren dapat memberikan solusi atas persoalan ekonomi tersebut. Keberhasilan ini, tidak terlepas dari nilai - nilai hidup yang ditanamkan kiai pengasuh pesantren kepada santrinya, salah satu nilainya yaitu kemandirian.

Kebutuhan masyarakat akan terbentuknya ekonomi syariah untuk menghilangkan keraguannya dari konsep riba membuat banyak pondok pesantren yang mendirikan dan membentuk lembaga keuangan dengan konsep syariah yaitu baitul maal attanwil yang berguna untuk semakin kuatnya ekonomi yang berlandaskan syariah. Dimana menurut pemaparan Bupati Pamekasan, pada tahun 2017 terdapat 160 koperasi syariah ${ }^{1}$. Adanya Koperasi syariah tersebut membuat lembaga pndok pesantren yang juga berkecimpung dengan lembaga keuangan tersebut sebagai contoh pendiriannya KSPPS BMT Mawaddah yang didirikan oleh Pondok Pesantren Miftahul Ulum Panyeppen.

Pamekasan merupakan kota pendidikan yang terdapat banyak pondok pesantren dan merupakan kota santri. Banyaknya Pondok pesantren di Pamekasan yang juga telah mendirikan atau membentuk Lembaga keuangan mikro syariah dengan tujuan untuk mengatasi persoalan ekonomi keumatan dan membangun kemandirian pondok pesantren. Kemandiran pondok pesantren dapat terbangun untuk kelangsungan hidup pondok pesantren dan kesejahteraan pondok pesantren saat ini maupun masa depan sehingga cita - cita pondok pesantren untuk menjadi lembaga yang mandiri dapat tercapai.

Penelitian ini bermaksud untuk menelaah dan membandingkan bagaimana kemandirian pondok pesantren dalam bidang ekonomi baik pondok pesantren yang memiliki usaha bisnis maupun pondok pesantren yang tidak memiliki usaha bisnis dalam membiayai penyelenggaraan pendidikannya. Sehingga memberikan kontribusi besar terhadap kemandirian pesantren secara umum. Penelitian ini

\footnotetext{
${ }^{1}$ www.republika.co.id.
} 
dilakukan pada seluruh pondok pesantren yang ada di Pamekasan baik yang memiliki usaha bisnis maupun tidak memiliki usaha bisnis.

Penelitian ini merupakan penelitian dasar dengan tujuan untuk mengetahui kemandirian pondok pesantren yang tidak memiliki usaha bisnis maupun yang memiliki usaha bisnis melalui pendirian lembaga keuangan mikro syariah dalam membiayai penyelenggaraan pendidikannya.

Kemandirian merupakan sifat yang ditunjukkan untuk tidak menggantungkan diri kepada orang lain, sehingga pesantren sebagai sebuah komunitas, mampu tumbuh dan berkembang yaitu dengan mengandalkan kemampuan sendiri, tanpa tergoda oleh kepentingan-kepentingan opurtunis dan kesenangan sesaat. Sikap ini ditunjukkan dengan posisi pesantren yang selalu menjaga jarak dengan penguasa, terutama ketika pesantren berada pada masa-masa sulit mulai zaman kolonial Belanda ${ }^{2}$.

Kemandirian adalah suatu keadaan ketika seseorang memiliki hasrat dan keinginan bersaing untuk maju demi kebaikan dirinya, mampu mengambil keputusan dan inisiatif untuk mengatasi masalah yang dihadapi, memiliki keoptimisan dalam mengerjakan tugas tugasnya, dan bertanggung jawab pada apa yang dilakukannya. Kemandirian merupakan identitas diri seorang muslim yang berlandaskan tauhid yang kuat, sehingga mampu menjadi khalifatul fi al-ardhi (divine vicegereny), bahkan dapat menjadi syuhada 'ala al-nas. Maka keyakinannya akan nilai tauhid menyebabkan setiap pribadi muslim akan memilki semangat jihad sebagai etos kerjanya. Dari semangat jihad ini dapat melahirkan keinginan untuk memperoleh hasil dan usaha atas karya dan karsa yang dibuahkan dari dirinya sendiri. Kemandirian bagi seorang muslim adalah lambang perjuangan semangat jihad (fighting spirit) yang sangat mahal harganya ${ }^{3}$.

Menurut ${ }^{4}$ menyebutkan bahwa ciri-ciri kemandirian adalah sebagai berikut: Pertama, mampu mengambil inisiatif. Kedua, mampu mengatasi masalah. Ketiga, penuh ketekunan. Keempat, memperoleh kepuasan dari usahanya.

Adapun faktor yang mempengaruhi kemandirian antara lain: faktor internal dan faktor eksternal. Faktor internal muncul dari dalam diri seseorang seperti motivasi dan kebutuhan seseorang 5 . Sebab pada dasarnya manusia menginginkan otonomi (bisa mengatur diri sendiri). Melepaskan diri dari kendala, ingin meloloskan diri dari kungkungan dan ketergantungan kepada orang lain. Sedangkan faktor internal meliputi dua hal ${ }^{6}$ yaitu Pertama, faktor kebudayaan. Kebudayaan masyarakat yang kompleks dan maju akan membentuk kemandirian yang lebih tinggi. Kedua, faktor pola asuh. Pola asuh yang bersifat demokratis, otoriter dan bebas akan mempengaruhi pada perkembangan kemandirian seseorang.

\footnotetext{
2 Solichin, Mohammad Muchlis. 2012. Kemandirian Pesantren Di Era Reformasi. Nuansa Vol. No. 1 Januari - Juni 2012.

3 Tasmara, T. 2002. Etos Kerja Pribadi Muslim. Yogyakarta: Dana Bhakti Prima Yasa.

4 Rofiq, Romdin A., A. Icep Fadlil Yani dan R.B. Widodo, 2005, Pemberdayaan Pesantren Menuju Kemandirian dan Profesionalisme Santri dengan Metode Daurah Kebudayaan, Yogyakarta: Pustaka Pesantren.

${ }^{5}$ Rofiq, Romdin A., A. Icep Fadlil Yani dan R.B. Widodo, 2005, Pemberdayaan Pesantren Menuju Kemandirian dan Profesionalisme Santri dengan Metode Daurah Kebudayaan, Yogyakarta: Pustaka Pesantren

${ }^{6}$ Hamidi, Jazim dan Mustafa Lutfi, 2010, Entrepreneurship Kaum Sarungan, Jakarta: Khalifa.
} 
Kemandirian Pondok pesantren dapat diukur dengan:

1. Adanya bisnis yang dibentuk oleh pesantren

2. $\quad$ Optimisme pesantren dalam mengelola bisnis yang ada

3. Eksistensi pondok pesantren dalam menghadapi persaingan ekonomi pondok pesantren

Lembaga Keuangan Syariah merupakan lembaga keuangan nonbank yang dalam transaksinya menggunakan prinsip syariah. Pondok pesantren di Pamekasan banyak yang mendirikan lembaga keuangan yang berprinsip syariah ini untuk mempertahankan kemandiriannya supaya tidak tergantung pada pihak eksternal pondok pesantren. Sebagai contoh KSPPS BMT Mawaddah yang merupakan unit usaha bisnis yang didirikan oleh pondok pesantren Panyeppen Pamekasan dan Koperasi Syariah Nuri yang didirikan oleh pondok pesantren Banyuanyar.

\section{Metode Penelitian}

Metode penelitian yang digunakan dalam penelitian ini adalah metode deskriptif kualitatif yaitu data yang dikumpulkan lebih megmbil bentuk kata-kata atau gambar daripada angka-angka. Hasil penelitian tertulis berisi kutipan dari data untuk mengilustrasikan dan meyediakan bukti. ${ }^{7}$ Jenis penelitian deskriptif kualitatif yang digunakan pada penelitian ini dimaksudkan untuk memperoleh informasi mengenai kemandirian pondok pesantren yang melalui bisnis lembaga keuangan dan kemandirian pesantren yang tidak memiliki bisnis.

Metode pengumpulan data merupakan salah satu aspek yang berperan dalam kelancaran dan keberhasilan dalam suatu penelitian. Dalam metode pengumpulan data yang digunakan dalam penelitian ini ada dua yaitu: Wawancara yang dilakukan terhadap beberapa informan diantaranya Pengasuh Pondok Pesantren, Pengurus Pondok Pesantren, Pengelola Lembaga Keuangan.

Obeservasi dalam penelitian ini dilakukan secara langsung, artinya peneliti akan melaksanakan tinjauan langsung kepada objek yang dituju, dalam hal ini peneliti akan berkunjung ke Pondok Pesantren yang ada di Pamekasan. Teknik Analisis Data yang dilakukan oleh penulis ada 3 tahapan yaitu: Reduksi data yaitu, proses pemilihan, pemusatan, perhatian, penyederhanaan, pengabstraksian dan transformasi data yang muncul dari hasil wawancara maupun observasi.

Dalam hal ini peneliti mengumpulkan informasi melalui wawancara terkait dengan informan yang berhubungan dengan perencanaan yang fokusnya kepada: Sikap kemandirian yang dapat mengatur sendiri dalam memenuhi kebutuhan barang dan jasa, Sikap kemandirian dalam memenuhi sendiri barang dan jasa. Sikap kemandiirian yang tidak bergantung pada orang lain dalam memenuhi kebutuhan barang dan jasa.

Data yang sudah didapat maka di reduksi sehingga akan memberikan gambaran yang jelas, dan mempermudah peneliti untuk melakukan analisis data selanjutnya. Penyajian Data, Proses kedua setelah reduksi data adalah penyajian data. Dalam penelitian kualitatif penyajian data biasanya disajikan dalam bentuk tabel, flow chart, diagram, grafik, dan sejenisnya. Penyajian data dalam penelitian ini adalah dengan cara mendeskripsikan hasil dari penelitian yang peneliti lakukan selama observasi dan wawancara. Dalam penyajian data penulis dapat mengetahui

\footnotetext{
${ }^{7}$ Emzir. 2016. Metodologi Penelitian Kualitatif. Rajawali pers. Jakarta.
} 
bagaimana perbandingan kemandirian pondok pesantren yang memiliki bisnis lembaga keuangan dan pondok pesantren yang tidak memiliki bisnis.

Menarik kesimpulan, Langkah terakhir dalam penelitian kualitatif adalah menarik sebuah kesimpulan dari permasalahan yang diteliti. Kesimpulan dalam penelitian kualitatif dapat menjawab rumusan masalah yang dirumuskan sejak awal tetapi mungkin saja tidak. Kesimpulan atau verifikasi dalam penelitian ini merupakan hasil dari penelitian yang telah dilaksanakan dalam bentuk pernyataan singkat dan mudah dipahami sehingga dapat menyimpulkan bagaimana kemadirian pondok pesantren yang memiliki bisnis lembaga keuangan dan kemandirian pondok pesantren yang tidak memiliki bisnis apapun.

\section{Pembahasan dan Hasil Penelitian}

Pamekasan dikenal dengan banyak berdirinya pondok pesantren. Berdirinya pondok pesantren tersebut tidak terlepas dari kiprah dari kiyai maupun nyai secara turun - temurun. Pondok pesantren di Pamekasan pada tahun 2019 berjumlah 222 pondok pesantren ${ }^{8}$ dan terdapat 32 pondok pesantren yang memiliki koperasi pondok pesantren ${ }^{9}$ serta terdapat 18 pondok pesantren yang memiliki lembaga keuangan syariah yaitu :

1. Koperasi Darul Falah dibawah naungan Pondok Pesantren Darul Falah.

2. Koperasi Al - Fatimy dibawah naungan Pondok Pesantren Al-Fatimy Tlanakan.

3. Koperasi Sumber Anyar dibawah naungan Pondok Pesantren Sumber Anyar.

4. Koperasi Miftahul Qulub dibawah naungan Pondok Pesantren Miftahul Qulub.

5. Koperasi Matsaratul Huda dibawah naungan Pondok Pesantren Matsaratul Huda Panempan.

6. Koperasi Al - Muchtar dibawah naungan Pondok Pesantren Nurul Ulum Karang Manggis.

7. Koperasi AUBA yang dibawah naungan Pondok Pesantren Mambaul Ulum Bata - Bata.

8. Koperasi Laa-Tansa yang dibawah naungan Pondok Pesantren Al - Abror Pamekasan.

9. Koperasi Al - Abdillah dibawah naungan Pondok Pesantren Al - Abdillah.

10. Koperasi Darul Ulum dibawah naungan Pondok Pesantren Darul Ulum.

11. Koperasi Al -Gazali dibawah naungan Pondok Pesantren Al- Gazali.

12. Koperasi Al - Mahbub dibawah naungan Pondok Pesantren Al - Mahbub.

13. Koperasi Al -Mubaraok dibawah naungan Pondok Pessantren Al-Mubarok.

14. Koperasi Bina Usaha dibawah naungan Pondok Pesantren Nasyrul Ulum Bagandan.

15. Koperasi Al Wafaa dibawah naungan Pondok Pesantren Ali Wafaa.

16. Koperasi Syariah Nuri dibawah naungan Pondok Pesantren Darul Ulum Banyuanyar.

17. Koperasi Al-Iqtishod Lil-Mu Amalah Mawaddah Syariah dan Koperasi Wanita Mawaddah dibawah naungan Pondok Pesantren Miftahul Ulum Panyeppen Pamekasan.

18. KSPPS BMT Al - Iktisab Kebun Baru Jawa Timur dibawah naungan Pondok

\footnotetext{
${ }^{8}$ www.ditpdpontren.kemenag.go.id.

${ }^{9}$ www.nik.depko.go.id.
} 
Pesantren Al -Iktisab Kebun Baru Palengaan.

Selain itu, objek pada penelitian ini yaitu pondok pesantren yang tidak memiliki lembaga keuangan yang dilakukan dengan survey yang menjadi sampel penelitian yaitu pada pondok pesantren Nurul Hikmah yang berlokasi di Blumbungan Pamekasan dan Pondok pesantren Miftahul Ulum Bettet Pamekasan.

\section{Perbedaan Pondok Pesantren Yang Memiliki Usaha Bisnis Dan Tidak Memiliki Usaha Bisnis}

Berdasarkan hasil survey dengan melakukan wawancara kepada Pengasuh dan pengurus pondok pesantren yang tidak memiliki usaha bisnis seperti pondok pesantren Nurul Hikmah Blumbungan dan Pondok Pesantren Miftahul Ulum Bettet Pamekasan diketahui bahwa dalam membiayai penyelenggaraan pendidikannya, pondok pesantren menggunakan dana pribadi pengasuh dan iuran dari para santri serta sumbangan dari para alumni dan masyarakat sekitar. Hanya pendidikan formal saja yang mendapatkan bantuan biaya pendidikan dari pemerintah yaitu berupa dana BOS. Sedangkan pondok pesantren yang memiliki usaha bisnis, dalam membiayai pendidikan selain dananya berasal dari iuran para santri dan dari pengasuh, juga berasal dari badan usaha yang didirikannya.

Salah satu badan usaha pondok pesantren yaitu lembaga keuangan syariah dalam bentuk koperasi syariah, dalam pendirian badan usaha tersebut modal yang didapatkan berasal dari dana pengasuh itu sendiri dibantu juga oleh para alumni serta masyarakat sekitar. Pada umumnya lembaga keuangan syariah yang dibentuk oleh pesantren dibawah legalitas hukum dinas koperasi serta kegiatan ekonominya yaitu simpan pinjam dengan akad - akad yang sesuai dengan syariah Islam seperti akad murabahah, mudharabah, salam, musyarakah, dll. Adanya lembaga keuangan syariah yang berada dibawah naungan pondok pesantren memiliki kontribusi besar terhadap perekonomian dan pembangunan pondok pesantren serta kegiatan lainnya, namun dana yang diberikan oleh lembaga keuangan syariah sebatas Sisa Hasil Usaha (SHU) yang berupa bagi hasil tiap tahun sesuai dengan modal yang disetorkan oleh pondok pesantren seperti halnya koperasi syariah Nuri yang berada dibawah naungan Pondok Pesantren Darul Ulum Banyuanyar. Berbeda halnya dengan Koperasi Syariah Al-Iqtishod Lil-Mu Amalah Mawaddah Syariah dan koperasi syariah al-iktisab kebun baru yang kontribusinya sangat besar terhadap biaya dan kemajuan pondok pesantren. Koperasi tersebut memberikan bagi hasil kepada pondok pesantren tidak sebatas modal yang disetorkan oleh pengasuh melainkan jumlah yang sangat besar hingga 1 milyar per tahunnya. Dengan embel naungan pondok pesantren, lembaga keuangan syariah lebih maju dan berkembang serta dapat mendirikan cabang LKS di tingkat kecamatan bahkan di tingkat kabupaten seperti lembaga keuangan syariah nuri yang berada dibawah naungan pondok pesantren darul ulum banyuanyar. ${ }^{10}$

Perkembangan Lembaga keuangan syariah tersebut tidak terlepas dari peran alumni santri, karena dalam pengelolaannya, lembaga keuangan syariah dikelola

\footnotetext{
10 Wardi M, Ismail I, Zainollah Z, Wekke IS. ENTREPRENEURSHIP AND FINANCING IN ISLAMIC EDUCATIONAL INSTITUTION OF DARUL ULUM BANYUANYAR PAMEKASAN. Acad Entrep J. 2019;25(2):1-14. https://www.abacademies.org/articles/Entrepreneurship-and-financing-inislamic-educational-institution-of-darul-ulum-banyuanyar-pamekasan-1528-2686-25-S2-287.pdf.
} 
oleh alumni santri yang dibuktikan dengan alumni dipilih dan ditunjuk langsung oleh kiai atau nyai sebagai karyawan dari LKS tersebut. Namun pada hasil studi lapangan, terdapat lembaga keuangan syariah yang kegiatan ekonominya sudah mulai menurun dan tidak efektif seperti lembaga keuangan pada umumnya. Hal ini disebabkan kurangnya pengetahuan manajemen alumni yang notabennya adalah santri dalam hal pengelolaan keuangan. Selain memiliki lembaga keungan syariah, pesantren juga memiliki usaha lainnya seperti Pondok Pesanten Miftahul Ulum Panyeppen yang memiliki Koperasi Pondok Pesantren yang menjual barang kebutuhan pokok, Lembaga Keuangan Mini Santri yang dikhususkan untuk menyimpan uang santri. Pondok Pesantren Azzubair Sumber Anyar dan Darul Ulum Banyuanyar juga memiliki badan usaha lainnya yaitu Koperasi Pondok Pesantren yang menjual berbagai macam barang kebutuhan pokok, dimana dalam kemajuannya juga tidak kalah maju dengan lembaga keuangannya karena juga memiliki kontribusi besar pada pembiayaan pondok pesantren.

Selain itu, pondok pesantren yang tidak memiliki badan usaha lembaga keuangan mikro syariah, mereka juga memiliki badan usaha lain seperti Koperasi Pondok Pesantren (KOPONTREN) yang kegiatan ekonominya di bidang penjualan bahan - bahan pokok untuk memenuhi kebutuhan santri dan pengelola pondok, usaha percetakan, butik, dll yang nantinya hasil dari kegiatan usaha tersebut digunakan untuk membiayai kebutuhan pondok pesantren dan penyelenggaraan pendidikan pondok pesantren seperti pembangunan pondok pesantren dan kemajuan pondok pesantren. Hal ini dapat dilihat pada Pondok Pesantren Miftahul Ulum Bettet dan Nurul Hikmah Blumbungan. Sehingga, walaupun tidak memiliki lembaga keuangan syariah, badan usaha lainnya dapat memiliki kontribusi besar terhadap pembiayaan pondok pesantren dan dalam menyelesaikan masaalah perekonomian pondok pesantren.

\section{Kemandirian Pondok pesantren}

Dalam mengatasi permasalahan ekonomi pondok pesantren, mereka mendirikan badan usaha yang dimiliki oleh pondok pesantren, baik itu lembaga keuangan mikro syariah maupun badan usaha pondok pesantren lainnya dapat menunjukkan kemajuan pondok pesantren untuk dapat bersaing baik di bidang ekonomi dan bidang lainnya pada era 4.0 saat ini. Sehingga tidak memiliki ketergantungan kepada pihak lain seperti pemerintah. Selain itu Rofiq (2005) ${ }^{11}$ menyebutkan bahwa ciri - ciri kemandirian adalah sebagai berikut:

Mampu Mengambil Inisiatif, Pondok pesantren merupakan lembaga informal yang tradisional, namun tetap diakui keberadaan dan kemajuannya di negara ini, namun dalam hal penyelengaaraan biaya pendidikannya, pondok pesantren bergantung pada dana yang diberikan oleh para alumni pondok pesantren, iuran pendidikan santri dan bantuan pemerintah, sehingga pada sampel penelitian ini, pondok pesantren mengambil inisiatif untuk membuka badan usaha seperti lembaga keuangan mikro syariah yang dimiliki oleh pondok pesantren darul ulum banyuanyar yaitu koperasi syariah nuri yang sudah memiliki cabang lintas

${ }^{11}$ Rofiq, Romdin A., A. Icep Fadlil Yani dan R.B. Widodo, 2005, Pemberdayaan Pesantren Menuju Kemandirian dan Profesionalisme Santri dengan Metode Daurah Kebudayaan, Yogyakarta: Pustaka Pesantren. 
kabupaten dan berbagai usaha lainnya yang juga nmemiliki kemajuan yng signifikan, miftahul ulum panyeppen yang memiliki LKS yaitu koperasi syariah BMT Mawaddah yang sudah memiliki cabang lintas kecamatan dan usaha lainnya yaitu koperasi pondok pesantren yang menjual berbagai barang kebutuhan, pondok pesantren al-iktisab kebun baru yang memiliki koperasi syariah al-iktisab kebun baru yang memiliki cabang lintas kecamatan dan koperasi pondok pesantren di bidang dagang, selain itu terdapat dua pondok pesantren yang juga memiliki lembaga keuangan syariah mikro yaitu pondok pesantren al- abror dan az-zubair sumber anyar yang sudah tidak efektif, namun legalitas pendiriannya masih tetap ada, selain itu juga memiliki bidang usaha lainnya seperti toko yang menjual bbarang - barang kebutuhan. Meskipun tidak memiliki lembaga keuangan mikro syariah, dalam kemaandiriannya untuk tidak bergantung pada pihk ketiga yaitu alumni dan pemerintah, pondok pesantren mengambil inisiatif dengan membuka usaha koperasi pondok pesantren yang bergerak dibidang penjualan barang kebutuhan pokok yaitu koperasi mahasiswa dan koperasi pondok pesantren, butik dan percetakan yang pengelolanya adalah santri pondok pesantren dan keseluruhan laporan pertanggungjawabannya dilaporkan kepada kiai atau nyai pondok pesantren setiap bulan yang digunakan untuk biaya penyelenggaraan pendidikan pondok pesatren.

Mampu Mengatasi Masalah, Pondok pesantren yang memiliki usaha bisnis baik itu lembaga keuangan mikro syariah maupun usaha bisnis lainnya mampu mengatasi masalah ekonomi dan keuangan pondok pesantren, karena pondok pesantren yang memiliki usaha bisnis mendapatkan pemasukan dana dari hasil usaha bisnis yang dijalankannya sehingga dapat membiayai penyelenggaraan pendidikan formal maupun informal apabila tidak ada bantuan pihak ketiga, hal ini juga diajarkan pada setiap santri untuk memiliki jiwa wirausaha yang baik untuk mecapai kemandirian diri sehingga menciptakan semangat entrepreneur yang kuat yang disebut juga santripreneur. berbeda halnya dengan pondok pesantren yang tidak memiliki usaha bisnis, mereka mengatasi masalah keuangan dan ekonominya dengan menggunakan uang pribadi pengasuh pondok pesantren dan bantuan dari alumni untuk biaya penyelenggaraan pendidikannya.

Penuh Ketekunan, Pada pengelolaan usaha bisnisnya, pondok pesantren memiliki ketekunan yang sangat baik sehingga mampu mengembangkan dan memajukan bisnis yang ada. Seperti lembaga keuangan syariah nuri yang dibawah naungan pondok pesantren Darul Ulum Banyuanyar, dengan ketekunannya alumni santri dalam mengelola LKS tersebut dapat mendirikan cabang LKS pada lintas kabupaten, selain itu badan usaha lainnya dari pondok pesantren darul ulum banyuanyar juga semakin berkembang pesat dan mengalami kemajuan dengan kesabaran dan ketekunan para santri dalam mengolah bisnis yang ada. lembaga keuangan syariah BMT Mawaddah yang dibawah naungan pondok pesantren Miftahul Ulum Panyeppen, dengan ketekunan dan keuletan pengelolaannya dapat mendirikan cabang LKS di tingkat kecamatan, serta koperasi syariah al - iktisab kebun baru yang berada dibawah naungan pondok pesantren al - iktisab kebun baru, dengan penuh ketekunan alumni dalam mengabdi di pondok pesantren yang menaungi LKS tersebut mampu mendirikan cabang LKS di lintas kecamatan, selain itu dengan penuh ketekunan dan penuh pengabdiannya santri kepada pondok 
pesantrennya, usaha bisnis lain pesantren al - iktisab kebun baru yaitu kopontren yang bergerak di bidang usaha penjualan bahan - bahan pokok memiliki cabang di berbagai kecamatan dan dikenal masyarakat luas serta mampu bersaing dengan mini market, supermarket dan toserba yang ada di pamekasan. Sehingga menunjukkan kemajuan yang sangat pesat.

Memperoleh Kepuasan dari usahanya, Pondok pesantren yang memiliki usaha bisnis memperoleh kepuasan dari usahanya yaitu keuntungan yang didapat dari setiap usahanya, laba yang didapatakan tersebut digunakan oleh pengasuh pondok pesantren untuk biaya penyelenggaraan pendidikan pondok pesantren seperti pembanguan asrama pondok pesantren, pembangunan lembaga pendidikan formal pesantren, yang saat ini pondok pesantren yang memiliki usaha bisnis seperti lembaga keuangan mikro syariah, mampu mendirikan lembaga pendidikan formal sampai perguruan tinggi seperti halnya pondok pesantren miftahul ulum panyeppen dan darul ulum banyuanyar. Sehingga pondok pesantren bukan lagi lembaga pendidikan yang tradisional dan kudet serta mampu bersaing dengan lembaga pendidikan formal lainnya. Oleh karenanya ada sinergi antara usaha bisnis yang didirikan oleh pondok pesantren dengan lembaga pendidikan pondok pesantren. Selain untuk membiayai penyelenggaraan pendidikannya, pondok pesantren menggunakan laba ynag didapatkan dari usaha bisnisnya dengan membuka cabang baru dan membuka usaha bisnis baru.

Menurut Rofiq (2005) ${ }^{12}$ dan Hamidi (2010) ${ }^{13}$ terdapat dua faktor yang mempengaruhi kemandirian pondok pesantren yaitu sebagai berikut:

Faktor Internal Yang Muncul Dari Dalam Pondok Pesantren, Keinginan Pondok Pesantren Darul Ulum Banyuanyar, Miftahul Ulum Panyeppen, Az - Zubair Sumber Anyar, Al - Abror, Miftahul Ulum Bettet Pamekasan, Nurul Hikmah Dan Kebun Baru untuk mampu bersaing dengan pendidikan formal yang ada serta tantangan zaman modern saat ini yang mengharuskan untuk menjadi lembaga yang mandiri mampu menjadi motivasi pondok pesantren dalam mendirikan usaha bisnis. Adanya kemajuan dan trending usaha di bidang keuangan mampu menumbuhkan motivasi beberapa pondok pesantren untuk mendirikan usaha lembaga keuangan mikro yang berlandaskan syariah. KSPPS Nuri yang berada dibawah naungan Pondok Pesantren Darul Ulum Banyuanyar, KSPPS BMT Mawaddah yang berada dibawah naungan Pondok Pesantren Miftahul Ulum Panyeppen, Koperasi Syariah Al - Iktisab Kebun Baru yang dibawah naungan Pondok Pesantren Kebun Baru, dll merupakan contoh dari perkembangan usaha pondok pesantren. Selain itu pada umumnya pondok pesantren memiliki usaha lainnya seperti toko, kopontren, percetakan, dll dalam memenuhi kebutuhan biaya penyelenggaraan pendidikan pondok pesantren, sehingga pesantren yang memiliki usaha bisnis yang besar dan LKS yang maju mampu membiayai sendiri penyelenggaraan pendidikannya tanpa harus ketergantungan kepada pihak ketiga seperti pemerintah yang sehingga tercipatanya kemandirian pesantren.

Faktor Eksternal Yang Berasal Dari Luar Pondok Pesantren, Kebudayaan lokal

\footnotetext{
12 Rofiq, Romdin A., A. Icep Fadlil Yani dan R.B. Widodo, 2005, Pemberdayaan Pesantren Menuju Kemandirian dan Profesionalisme Santri dengan Metode Daurah Kebudayaan, Yogyakarta: Pustaka Pesantren

13 Hamidi, Jazim dan Mustafa Lutfi, 2010, Entrepreneurship Kaum Sarungan, Jakarta: Khalifa.
} 
dengan banyaknya peluang bisnis yang ada dan kebutuhan masyarakat terhadap transaksi yang halal dan jauh dari riba mampu membentuk pesantren untuk mendirikan lembaga keuangan mikro syariah yang transaksinya berlandaskan syariah. Dari modal yang disetorkan oleh pengasuh kepada LKS yang dikelola oleh alumni pondok pesantren mampu menghasilkan bagi hasil yang nantinya kembali lagi kepada pesantren yang digunakan untuk biaya penyelenggaraan pendidkan pondok pesantren. Selain itu, banyaknya masyarakat yang mendirikan UMKM menjadi landasan pondok pesantren untuk membuka usaha bisnis. Dan adanya pola asuh yang demokratis dan bebas untuk membuka usaha menciptakan keinginan pesantren untuk membuka usaha seperti LKS, Kopontren, butik, percetakan, toko, dll. Sehingga hasil keuntungan dari usaha tersebut pondok pesantren tidak lagi ketergantungan kepada pemerintah, almuni, dan pihak ketiga lainnya sehingga menciptakan kemandirian ekonomi pada pondok pesantren.

\section{Ukuran Kemandirian Pondok Pesantren}

Adanya Bisnis yang Dibentuk Oleh Pesantren, Pondok pesantren az-zubair sumber anyar Tlanakan memiliki usaha bisnis Lembaga keuangan mikro syariah yaitu KSPPS Sumber Anyar namun LKS ini kurang efektif karena tutup sementara dan masih ada perbaikan dari manajemen LKS dan toko, Pondok pesantren kebun baru Palengaan memiliki usaha bisnis KSPPS BMT Al - Iktisab Kebun Baru Pamekasan yang memiliki cabang di beberapa kecamatan di Pamekasan, Kopontren yang menjual berbagai macam kebutuhan poko dan memiliki cabang di beberapa kecamatan, koperasi dan toko di dalam pondok pesantren, Pondok Pesantren Darul Ulum Banyuanyar Pamekasan memiliki usaha bisnis Koperasi Syariah Nuri yang bergerak di bidang simpan pinjam keuangan syariah, Kopontren di dalam pondok pesantren yang menjual berbagai barang kebutuhan sebanyak 2 kopontren, dan toko yang berada di dalam pondok pesantren, perusahaan air minum NURI yang dikelola oleh alumni santri pondok pesantren, Pondok Pesantren Miftahul Ulum Panyeppen Pamekasan memiliki usaha bisnis keuangan syariah yaitu Koperasi AlIqtishod Lil-Mu Amalah Mawaddah Syariah dan Koperasi Wanita Mawaddah yang bergerak di sektor simpan pinjam keuangan syariah, kopontren yang berada di dalam pondok pesantren putra yang menjuual berbagai barang kebutuhan pokok dan toko yang berada di pondok pesantren putri yang juga menjual barang kebutuhan pokok, Pondok Pesantren Al - Abror Pamekasan memiliki usaha bisnis keuangan yaitu Laa - Tansa yang bergerak di bidang usaha simpan pinjam lembaga keuangan mikro syariah namun LKS ini sudah kurang efektif. Selain itu Pondok Pesantren $\mathrm{Al}$ - Abror memiliki toko yang menjual berbagai macam kebutuhan pokok untuk santri yang berada di dalam pondok pesantren, Pondok Pesantren Nurul Hikmah Masih Tidak Memiliki Usaha Bisnis, dan Pondok pesantren Miftahul Ulum Bettet Pamekasan tidak memiliki usaha bisnis Lembaga keuangan mikro syariah, namun memiliki beberapa bisnis yang berada di dalam kompleks pesantren yaitu koperasi mahasiswa (KOPMA), Percetakan miftahul ulum, kopontren yang berada di dalam pondok pesantren yang terdiri dari 2 kopontren yang berada di pondok pesantren putra dan putri yang menjual barang kebutuhan pokok santri, toko yang terdiri dari 2 toko yang masing-masing berada di pondok pesantren putra dan putri yang menjual makanan, snack,dan ikan, butik yang berada di dalam pondok 
pesantren putri yang menjual berbagai macam fashion mulai dari bros, dll hasil karya dari santri putri, wedding make-up yang berada di dalam pondok pesantren putri. Semua usaha bisnis pondok dikelola oleh para santri putra maupun putri.

Optimisme Pesantren Dalam Mengelola Bisnis Yang Ada, Pondok pesantren optimis dalam mengelola bisnis yang dimilikinya, hal ini dapat dilihat pada perkembangan bisnis pondok pesantren yang semakin meningkat yang ditunjukkan dengan bisnis yang dijalankan banyak membentuk cabang baik tingkat kecamatan seperti KSPPS BMT Mawaddah dan KSPPS BMT al-iktisab kebun baru maupun tingkat kabupaten seperti koperasi syariah nuri dan hasil laporan pertanggungjawaban tiap bulannya bahwa bisnis yang dijankan oleh usaaha pondok pesantren mengalami keuntungan. Selain itu para pengelola berasal dari santri sendiri yang pada dasarnya mereka mengelola karena takdzim kepada gurunya yaitu kiai atau nyai dan hanya ngamri barokah sehingga tidak mengharapkan nominal yang mereka dapatkan.

Eksistensi Pondok Pesantren Dalam Menghadapi Persaingan Ekonomi Pondok Pesantren, Adanya label nama maupun lambang pondok pesantren pada usaha bisnis pondok pesantren memiliki eksistensi yang kuat pada kemajuan usaha bisnis pondok pesantren. Sehingga dengan kemajuan bisnis memiliki kontribusi yang besar untuk kemajuan pondok pesantren baik dalam bidang ekonomi maupun dalam sektor pembangunan pondok pesantren. Selain itu usaha bisnis pondok pesantren mampu menghadapi persaingan ekonomi lokal yang berasal dari non pesantren, hal ini dapat ditunjukkan dari banyaknya cabang lembaga keuangan mikro syariah yang dibentuk di tiap kecamatan khususnya didaerah pantura, seperti Koperasi syariah Nuri yang sudah memiliki cabang di luar Kabupaten Pamekasan, dan KSPPS BMT Mawaddah dan KSPPS Al-Iktisab Kebun Baru yang memiliki kantor cabang yang berada di beberapa kecamatan seperti Pakong, Pasean, Pamekasan, Blumbungan, dll. Adanya kopontren yang lengkap dan harga dapat dijangkau masyarakat dapat mengalahkan toko toserba yang ada di lingkungan sekitar sehingga dapat menjadi keunggulan dari pondok pesantren. Selain itu, pembangunan pondok pesantren dan lembaga pendidikan formal yang semakin kompleks dan megah membuktikan eksistensi kemandirian pondok pesantren dalam persaingan ekonomi di bidang usaha yang dijalankannya.

\section{Penutup}

Berdasarkan hasil dan pembahasan diatas dapat disimpulkan bahwa dengan banyaknya, berkembangnya dan semakin majunya usaha bisnis pondok pesantren dapat menciptakan pondok pesantren yang mandiri dan tidak tergantung terhadap pihak kertiga baik itu pemerintah maupun alumni santri serta iuran dari santri, namun dengan adanya lembaga keuangan mikro syariah hanya memberikan kontribusi kepada pondok pesantren setiap tahun dari sisa hasil usaha (SHU) yang didapatkan dari lembaga keuangan mikro syariah, keuntungan juga diperoleh dari usaha bisnis pesantren yang lainnya. Sehingga adanya usaha bisnis yang dijalankan menciptakan kemandirian pondok pesantren di bidang ekonomi dan pembangunan. Sedangkan pesantren yaang tidak memiliki usaha bisnis masih ketergantungan kepada bantuan yng diberikan oleh alumni, iuran santri, dan proyek yang diberikan oleh pemerintah. 


\section{Daftar Pustaka}

Emzir. Metodologi Penelitian Kualitatif. (Jakarta: Rajawali Pers, 2016).

Hamidi, Jazim dan Mustafa Lutfi. Entrepreneurship Kaum Sarungan. Jakarta: Khalifa, 2010).

Mannan, Faidul. Perancangan Sistem Informasi Akuntansi Pada Pondok Pesantren Salafiyah Syafi'iyah Nurul Huda Mergosono Malang. (Malang: Universitas Islam Negeri Maulana Malik Ibrahim, 2018).

Misjaya, Dkk. Konsep Pendidikan Kemandirian Ekonomi Di Pondok Pesantren Mukmin Mandiri Sidoarjo - Jawa Timur. (Edukasi Islam : Jurnal Pendidikan Islam, Vol. 08/No: 01, Februari 2019).

Rofiq, Romdin A., A. Icep Fadlil Yani dan R.B. Widodo. 2005. Pemberdayaan Pesantren Menuju Kemandirian dan Profesionalisme Santri dengan Metode Daurah Kebudayaan. (Yogyakarta: Pustaka Pesantren, 2005).

Sanusi, Uci. Pendidikan Kemandirian Di Pondok Pesantren (studi mengenai realitas kemandirian santri di pondok pesantren Bahrul Ulum Tasikmalaya). (Jurnal Pendidikan Agama Islam Ta'lim : Vol. 10 No. 2, 2012).

Solichin, Mohammad Muchlis. Kemandirian Pesantren Di Era Reformasi. (Nuansa: Vol. No. 1, Januari - Juni 2012).

Tasmara, T. Etos Kerja Pribadi Muslim. (Yogyakarta: Dana Bhakti Prima Yasa, 2002). Wardi M, Ismail I, Zainollah Z, Wekke IS. ENTREPRENEURSHIP AND FINANCING IN ISLAMIC EDUCATIONAL INSTITUTION OF DARUL ULUM BANYUANYAR PAMEKASAN. Acad Entrep J. 2019;25(2):1-14. https://www.abacademies.org/articles/Entrepreneurship-and-financing-inislamic-educational-institution-of-darul-ulum-banyuanyar-pamekasan1528-2686-25-S2-287.pdf.

www.republika.co.id. www.ditpdpontren.kemenag.go.id www.nik.depko.go.id 